\title{
Transit-Time Flow Measurement: Letter to the Editor
}

\section{Elsayed Elmistekawy}

Cardiac Surgery, Ottawa Heart Institute, Ottawa, Canada.

Email: Elmistekawy@yahoo.com

Received February $12^{\text {th }}, 2012$; revised March $11^{\text {th }}, 2012$; accepted March $18^{\text {th }}, 2012$

\begin{abstract}
Transit-time flow technology is considered as a quality of care in bypass surgery especially in off pump revascularization. Transit time flow measurement is a real time, direct, easy and handy tool for assessment quality of anastomosis and graft blood flow.
\end{abstract}

Keywords: Transit Time Flow; Coronary Artery Bypass Grafting

\section{To the Editor}

I read with interest the article of Dalyanoĝlu et al. in [1] and would like to congratulate the authors for this excellent results and study.

Transit-time flow technology is considered as a quality of care in bypass surgery especially in off pump revascularization. Transit time flow measurement is a real time, direct, easy and handy tool for assessment quality of anastomosis and graft blood flow. It could detect anasomotic and graft alignment problems that can be managed by revision of the graft and anastomosis while the chest is open without the need for angiography [2-5].

I have some comments and inquiries to authors:

1) The average age of the study population is 67 years that means young patients with preserved left ventricular function (Ejection fraction $>50 \%$ ) however only 27 patients had Left Internal mammary artery (LIMA) and the rest of the grafts were saphenous vein graft:

a) Is those patients were selected for the purpose of the study?

b) I wonder why 4 cases had no LIMA graft.

c) What about other arterial conduit in this young group of patients (Right internal mammary artery, Radial artery)?

2) What was the time of graft flow measurement: After or before protamine?

3) Graft revision was required in 2 cases:

Case 1:

Did the authors determine that the problem was in the anastomosis or graft alignment? Revision of the distal anastomosis was done and results shown in Figure 2(b); in fact the figure shows unacceptable graft blood flow with graft flow $2 \mathrm{ml} / \mathrm{min}$, pulsatility index 11.0 and DF $1 \%$.
Case 2:

The authors stated the TTFM measurement revealed non-functional LITA-graft (Figure 3). However the numbers and curve in Figure 3 (Flow $13 \mathrm{ml} / \mathrm{min}$, PI 3.3 and DI $84 \%$ ) are acceptable. What are the cut off point for these 3 parameters that the authors used to decide that graft need to be revised?

4) Were the cardiac enzyme marker measured in those patients after surgery especially for those 2 cases that required graft revision?

5) Although the number of patients in this study is small (31 patients) but I agree with their conclusion that TTFM should be performed routinely in all CABG to improve patient care and quality of surgical results.

\section{Conclusion}

The transit time technology should be a quality measure in bypass surgery.

\section{REFERENCES}

[1] H. Dalyanoĝlu, H. Kamiya, M. Kurt, M. Thöne, P. Akhyari, A. Lichtenberg and B. Korbmacher, "Graft Quality Control with the Traditional Roller Pump Flow Measurement in Comparison to the Transit-Time Flow Measurement," Open Journal of Thoracic Surgery, Vol. 1, No. 2, 2011, pp. 9-11. doi:10.4236/ojts.2011.12002

[2] M. Yamamoto, S. Sasaguri and T. Sato, "Assessing Intraoperative Blood Flow in Cardiovascular Surgery," Surgery Today, Vol. 41, No. 11, 2011, pp. 1467-1474. doi:10.1007/s00595-010-4553-0

[3] K. B. Kim, C. H. Kang and C. Lim, "Prediction of Graft Flow Impairment by Intraoperative Transit Time Flow Measurement in Off-Pump Coronary Artery Bypass Using Arterial Grafts," The Annals of Thoracic Surgery, Vol. 
80 , No. 2, 2005, pp. 594-598.

doi:10.1016/j.athoracsur.2005.02.047

[4] C. Schmitz, O. Ashraf, W. Schiller, C. J. Preusse, B. Esmailzadeh, J. A. Likungu, R. Fimmers and A. Welz, "Transit Time Flow Measurement in On-Pump and Off -Pump Coronary Artery Surgery," The Journal of Tho- racic and Cardiovascular Surgery, Vol. 126, No. 3, 2003, pp. 645-650. doi:10.1016/S0022-5223(03)00018-7

[5] E. Elmistekawy, "Comparison of Graft Flow in off Pump and Conventional Coronary Artery Bypass Grafting," Journal of the Egyptian Society of Cardiothoracic Surgery, Vol. 13, No. 1, 2005, pp. 16-20. 